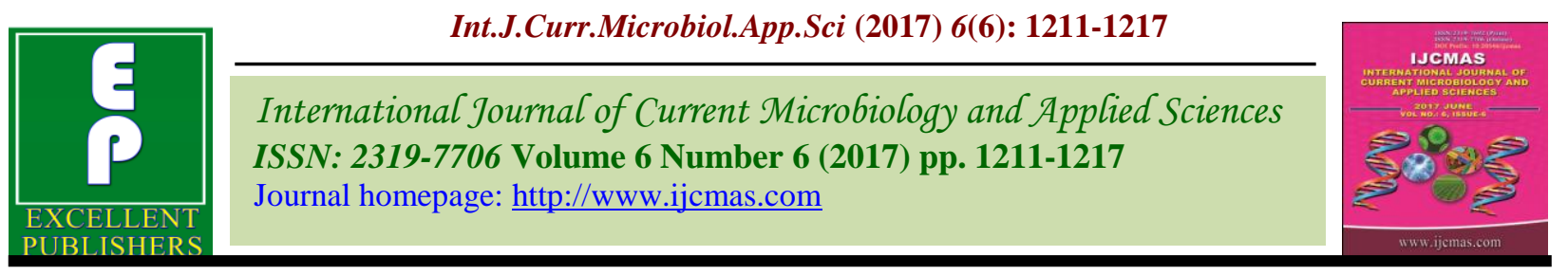

Original Research Article

https://doi.org/10.20546/ijcmas.2017.606.140

\title{
Study of Economics of Manual and Mechanical Harvesting Method of Sorghum Crop
}

\author{
M.D. Nikam* , S.H. Thakare, V.P. Khambalkar and S.S. Karhale \\ College of Agricultural Engineering and Technology, Dr. P.D.K.V. Akola, (M.S.), India \\ *Corresponding author
}

A B S T R A C T

The performance evaluation of hydraulically operated sorghum harvester was evaluated in different field and for different varieties of sorghum at western block

\begin{tabular}{|l|}
\hline Ke y w or d s \\
Sorghum harvester, \\
Mechanical \\
harvesting, Manual \\
harvesting, \\
Operating cost etc. \\
\hline Article Info \\
\hline Accepted: \\
19 May 2017 \\
Available Online: \\
10 June 2017 \\
\hline \hline
\end{tabular}
and Sorghum research unit during harvesting season of 2011-12. The system were evaluated according technical parameters like actual field capacity, field efficiency, fuel consumption and operating cost of harvesting method using standard procedure. The average operating speed of mechanical harvesting method was $2.29 \mathrm{~km} / \mathrm{h}$. Average Effective field capacity and field efficiency of mechanical harvesting was found to be $0.299 \mathrm{ha} / \mathrm{h}$ and 72.36 per cent respectively Average time required per hectare in mechanical harvesting $3.4 \mathrm{hr}$ where as in manual harvesting it was $7.5 \mathrm{hrs}$ with net saving of 54.67 per cent. Total man hours required per hectare in mechanical harvesting were $6.8 \mathrm{hrs}$ where as in manual harvesting it was around 150 hrs. So, net saving in man hour's requirement in mechanical harvesting over manual harvesting was around 95.47 per cent. Total cost of operation for harvesting by tractor operated sorghum harvester was found to be Rs. 3318.12/ha. In manual harvesting it was found to be Rs. 5000/ha. The net saving in the cost of operation per hectare was found to 33.64 per cent over manual harvesting.

\section{Introduction}

Sorghum or Jowar [Sorghum bicolour (L.)] is one of the most important cereal crops and it is the fifth most important cerealcrop in the world, after wheat, maize, rice and barley; whereas in India sorghum is the third cereal crop after rice and wheat (Charyulu, 2011). It is a staple food for millions of poor rural people in Asian and African countries. Besides being a major source of staple food for human beings, it also serves as an important source of fodder, animal feed and industrial raw material. On global front, sorghum was grown in 105 countries of the world in the year 2010-11 covering an area of approximately $40.5 \mathrm{~m}$ ha with grain production of $55.65 \mathrm{~m}$ tons and an average productivity of 1.374 tons per ha (Charyulu, 2011). In March 2014 United State Department of Agriculture (USDA) estimated that the world sorghum production 2013-14 will be 61.26 million metric tons.

In India, the crop is primarily produced in Maharashtra and Southern states of Karnataka 
and Andhra Pradesh, these three major states together accounts for close to $80 \%$ of the all India production of sorghum. Madhya Pradesh, Gujarat and Rajasthan are the other states growing sorghum. India is the third largest producer of sorghum in the world with 7.98 million tons during 2012 and almost entire production of sorghum $(95 \%)$ in the country comes from the above regions/states (GOI, 2007).

The total harvesting of sorghum requires two stages cutting of plant, one at the top for separating cobs and second at the bottom for fodder. Hence double operation is required for harvesting of this crop. Sorghum has created the possibility of mechanizing the harvesting of cobs due to the genetical property. The solution of this problem could be achieved by tractor with separate mechanism for cutting the cobs (i.e. nipping) and simultaneously cutting the plant from its bottom (i.e. reaping) (Kanafoiski and Karwowski, 1976). Harvesting of this crop requires considerable amount of labour, drudgery and time. The mechanization of agriculture not only reduces the overall cost of production but also increases the total agricultural yield. Through mechanized farming, many countries in the world are reaching the upper limits of their cultivable land. The increasing use of agricultural machinery, equipments and fertilizers coupled with better irrigation facilities, together revolutionizes the agricultural sector.

Harvesting, the gathering of a ripened crop, is the most important stage of the cultivation process. In the past, when harvesting was done manually, a substantial portion of the crop was wasted. But, with the introduction of harvesting machines, harvesting has become cheaper and easier than ever. Harvesting machine not only saves the time but also reduces the quantity of waste to a great extent.
Hence the present study was aimed to develop tractor front mounted sorghum harvester that will cut the cobs and convey to collection box as well as windrow the stalks of sorghum efficiently and economically. To improve the performance of cutting and nipping unit of Sorghum harvester and to analyze the cost economics, the present study was undertaken.

\section{Materials and Methods}

The testing trials of sorghum harvester were conducted on various fields for performance evaluation to determine field capacity, field efficiency, harvesting losses, cost of operation etc and compared with the manual harvesting method of sorghum. Different parameters like average stem diameter, moisture content, average height of the grain sorghum stalks were recorded to study the suitability of the harvester for grain sorghum. During the trials various parameter were recorded as given below;

Moisture content of sorghum stalks

Speed of operation

Effective field capacity

Theoretical field capacity

Field efficiency

Fuel consumption

Cost of operation

\section{Cost of operation}

The cost of operation for tractor operated sorghum harvester was calculated using the standard procedure including the parameters such as fixed and variable cost of tractor and sorghum harvester. Also the cost of operation for manual harvesting of sorghum crop was calculated for comparing the cost of operation for both mechanical and manual method of harvesting.

The cost of operation is divided under two heads known as fixed cost and operating cost. 
Fixed cost includes:

Depreciation

Interest on capita

Housing

Insurance

Taxes

\section{Operating cost includes}

Fuel

Lubricants

Repair and Maintenance

Wages

\section{Results and Discussion}

Sorghum was harvested using traditional method (using sickle) as well as with the sorghum harvester. The performance data were collected and analyze to assess the efficiency of mechanical harvester, operating losses of machine as well as labour cost. During the field trial the harvester operated at speed of $2 \mathrm{~km} / \mathrm{h}$ to $3 \mathrm{~km} / \mathrm{h}$. Speed above the specified limit cause losses and blockage at cutting unit due to higher stem strength and density of crop. In order to avoid this problem harvester were operated less than $3 \mathrm{~km} / \mathrm{h}$. Increased in operating speed cause increase in theoretical field capacity and fuel consumption in other word increase the cost of operation also reduce the cutting efficiency of cutting unit. The test trials were conducted according to standard procedure and the results obtained in tests are presented in table 1.

The average effective field capacity in mechanical harvesting was found to be 0.299 $\mathrm{h} a / \mathrm{h}$ whereas $0.133 \mathrm{ha} / \mathrm{h}$ in manual harvesting. The average theoretical field capacity of tractor operated sorghum harvester was found to be $0.413 \mathrm{ha} / \mathrm{h}$. The average field efficiency of tractor operated sorghum harvester was found to be 72.36 per cent. Average time required per hectare in mechanical harvesting $3.4 \mathrm{hr}$ where as in manual harvesting it was $7.5 \mathrm{hrs}$ with net saving of 54.67 per cent.

Fig.1 Percent saving in mechanical method over traditional method of Sorghum harvesting

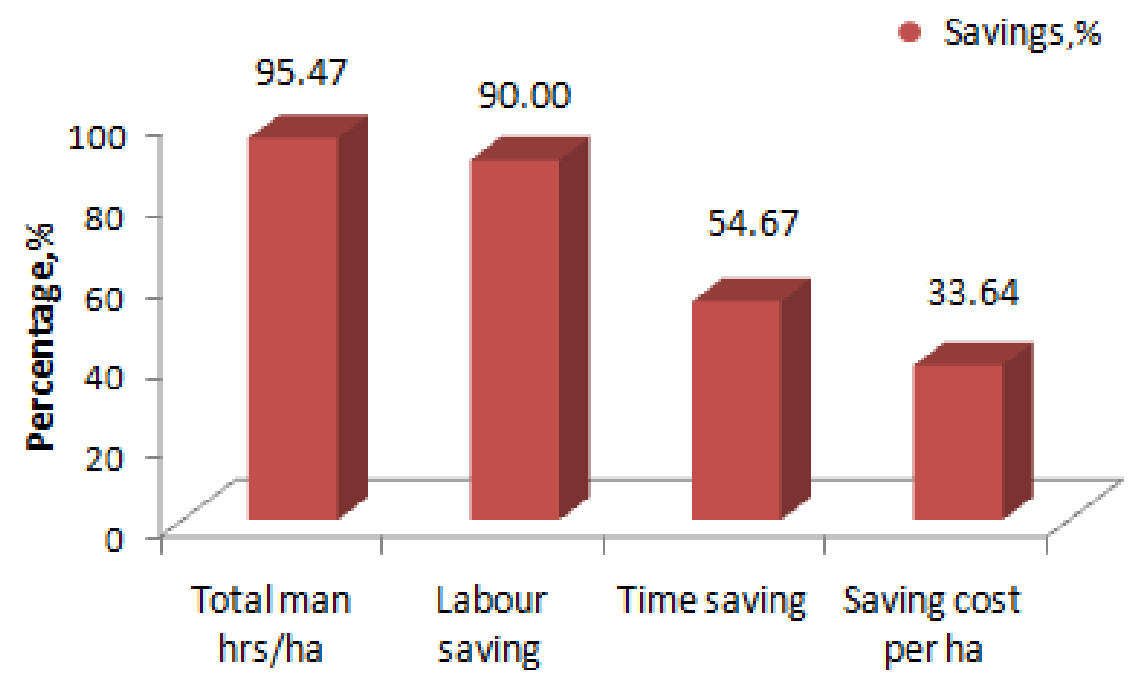

Perticulars 
Manual harvesting

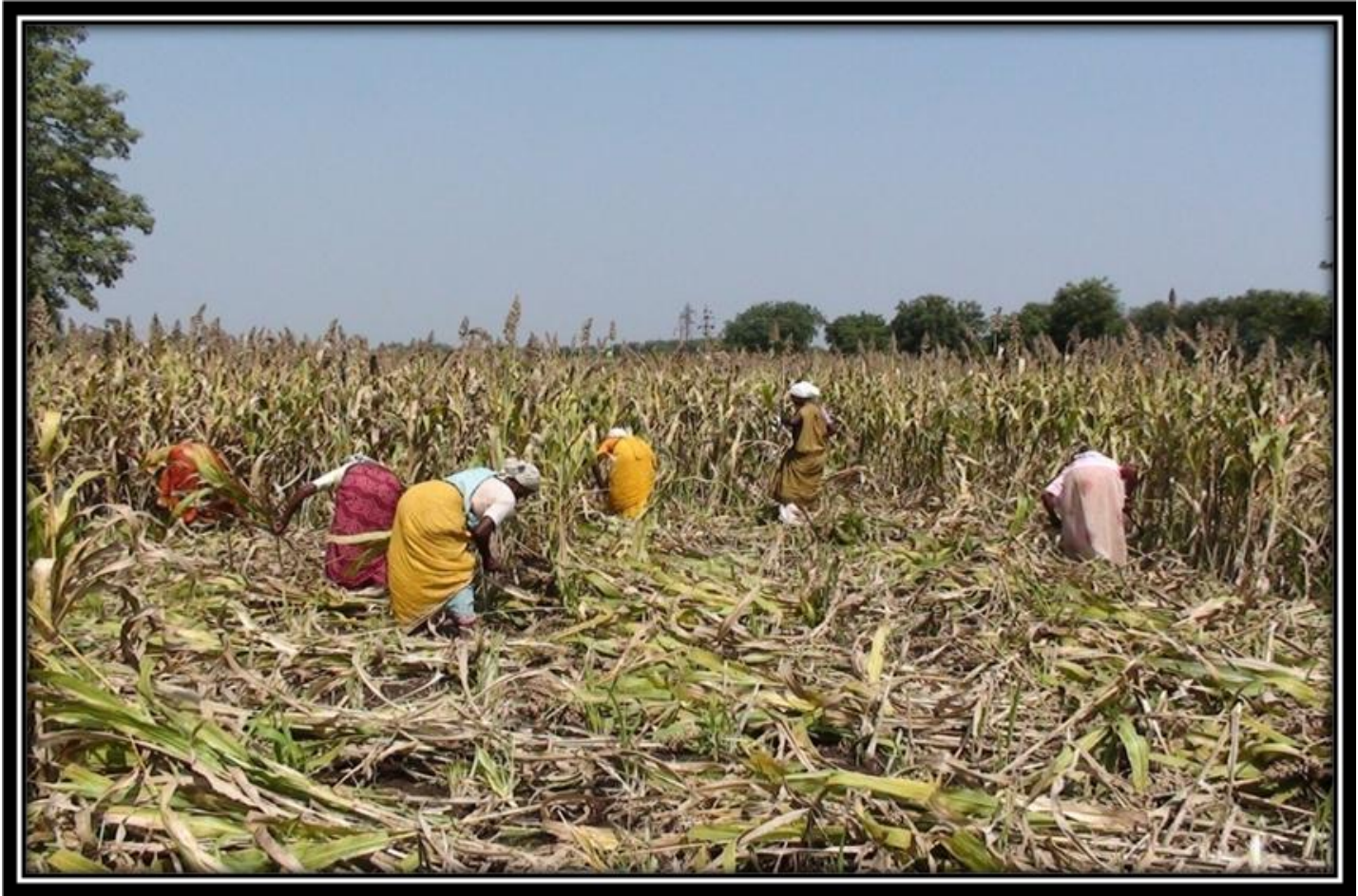

Field harvested by sorghum harvester

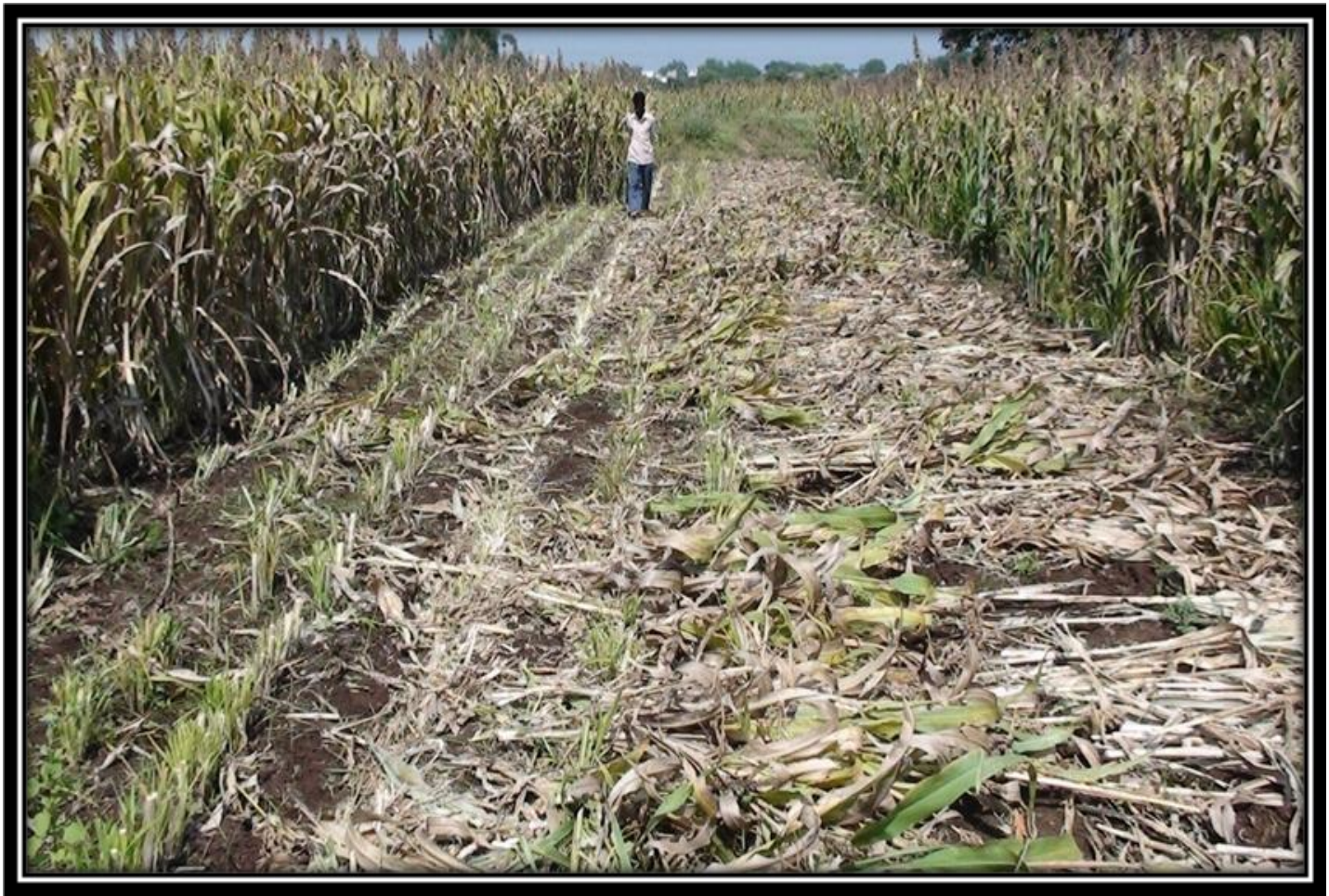


Table.1 Evaluation of mechanical and traditional methods of sorghum harvesting

\begin{tabular}{|c|c|c|c|}
\hline \multirow[b]{2}{*}{ S.No. } & \multirow[b]{2}{*}{ Parameters } & \multicolumn{2}{|c|}{ Harvesting Methods } \\
\hline & & Mechanical & $\begin{array}{c}\text { Traditional } \\
\text { (Manual) }\end{array}$ \\
\hline 1 & Method used & Mechanical & Traditional \\
\hline 2 & Power Source & Tractor & Man power \\
\hline 3 & $\begin{array}{l}\text { Lab our charge, } \\
\text { Rs/day/man }\end{array}$ & $250-300$ & 250 \\
\hline 4 & $\begin{array}{l}\text { Total number of labours } \\
\text { required per hectare }\end{array}$ & $\begin{array}{c}2 \text { (1 operator \& } 1 \\
\text { labour })\end{array}$ & 20 labours/ha \\
\hline 5 & $\begin{array}{l}\text { Actual time required, } \\
\text { h/ha }\end{array}$ & 3.40 & 7.5 \\
\hline 6 & $\begin{array}{l}\text { Actual field capacity, } \\
\text { ha/h }\end{array}$ & 0.299 & 0.133 \\
\hline 7 & $\begin{array}{l}\text { Total man hours } \\
\text { requirement, man-hrs/ha }\end{array}$ & 6.8 & 150 \\
\hline 8 & $\begin{array}{l}\text { Total cost of labour } \\
\text { required, Rs/ha }\end{array}$ & 550 & 5000 \\
\hline 9 & $\begin{array}{l}\text { Total cost of operation per } \\
\text { hectare, Rs/ha }\end{array}$ & 3318.12 & 5000 \\
\hline
\end{tabular}

Total man hours required per hectare in mechanical harvesting were $6.8 \mathrm{hrs}$ where as in manual harvesting it was around $150 \mathrm{hrs}$. So, net saving in man hour's requirement in mechanical harvesting over manual harvesting was around 95.47 per cent. Total cost of operation for harvesting by tractor operated sorghum harvester was found to be Rs. 3318.12/ha. In manual harvesting it was found to be Rs. 5000/ha. The net saving in the cost of operation per hectare was found to 33.64 per cent over manual harvesting (Fig 1).

The overall performance of sorghum harvester was satisfactory. Average time required per hectare in mechanical harvesting $3.4 \mathrm{hr}$ where as in manual harvesting it was 7.5 hrs with net saving of 54.67 per cent. Total cost of operation for harvesting by tractor operated sorghum harvester was found to be Rs. 3318.12/ha. In manual harvesting it was found to be Rs. 5000/ha. The net saving in the cost of operation per hectare was found to 33.64 per cent over manual harvesting.
Thus it is feasible to reduce the harvesting cost of sorghum by using mechanical harvesting method and it is more convenient that harvesting of sorghum by sorghum harvester is much more easy and quicker than manual harvesting by sickle. Thus sorghum harvester is more suitable for farmer for harvesting sorghum.

\section{References}

Allen, R.R. and L.D. Hollingsworth. 1981. Combine header performance in Lodged grain sorghum. Trans. ASAE, (24): 1426-1428 and 1431.

Anonymous. 2007. GOI, Agriculture statistics at a glance, Directorate of Economics and Statistics. New Delhi, India: Ministry of Agriculture, Government of India.

Anonymous. 2013. Informa Economics Survey-Based Crop Reporting Service.

Anonymous1. 2011. Crop Production, Worldwide, FAOSTAT, Food and 
Agriculture Organization of the United Nations.

Anonymous2. 2011. Directorate of Economics and Statistics, Department of Agriculture and Co-operation.

Bedane, G.M., M.L. Gupta and D.L. George. 2008. Development and Evaluation of a Guayule Seed Harvester. Indus. Crops Products, 28: 177-183.

Bhende, S.M. and M.A. Bhamodkar. 2006. Hydrostatic drive system for sorghum harvester. New Agriculturist, 17(1,2): 207-214.

Charyulu, D.K., M.C.S. Bantilan, S. Nedumaran and U.K. Deb. 2011. Development and Diffusion of Improved Sorghum Cultivars in India: Impact on Growth and Variability in Yield (ICRISAT).

Kanafojski, C.L. and J. Karwowski. 1976. Agricultural machines, theory and construction. Vol. 2 Foreign scientific publication Department of the National Center for Scientific Technical and Economic information, Warsaw, Polland, 141 - 228 and 627 - 726.

Kenner, W.E., M.A. Nealet, and R.E. Arnold. 1987. A new Concept in Combine Harvester headers. J. Agril. Engg. Res., 38(1): 37-45.

Klenin, N.I., I.F. Popov and V.A. Sakun. 1985. Agriculture Machines.Amrind Publishing Co., New Delhi: 280-293, 358-368.

Koloor, T.R. and A. Borgheie. 2006. Measuring the Static and Dynamic Cutting Force of Stems for Iranian Rice Varieties. J. Agric. Sci. Technol., 8: 193-198

Mckemie, G.R. and J.S. Cundiff. 1979. Computer Aided Design of Hydrualic System. Trans. ASAE, 22(5): 10231028.

Mehata, M.L., S.R. Verma, S.K. Mishra and S.K. Sharma. 2005. Text book of Testing and Evaluation of Agricultural machinery, Daya Publication House, New Delhi.

Mohammadi, N. and N. Hosein. 2012. Design and Development of a Cutting Head for Portable Reaper Used in Rice Harvesting Operations. J. Appl. Biol. Sci., 6(3): 69-75

Oduori, M.F., T.O. Mbuya, J. Sakai and E. Inoue. 2012. Kinematics of the tined combine harvester reel. Agric. Eng. Int. CIGR J., 14(3): 53-60.

Oduori, M.F., T.O. Mbuya, J. Sakai and E. Inoue. 2012. Modelling of crop stem deflection in the context of combine harvester reel design and operation. Agric. Eng. Int. CIGR J., 14(2): 21-28.

Ojomo, A.O., M.P. Ale and O.G. Olajide. 2010. Development and Performance Evaluation of a Cowpea Harvester. $J$. Appl. Engi. Sci., 5. No. 10.

Pandey, M.M. 1999. Trend of Research and development of farm machinery in India during last three decades. Paper presentation during National Seminar on Farm Mechanization held at CIAE, Bhopal during Sept. 21-22, 1999.

Pawar, C.S., N.A. Shirsat and S.V. Pathak. 2008. Performance Evaluation of Combine Harvester and Combination of Self Propelled Vertical Conveyor Reaper with Thresher for Wheat Harvesting. Agri. Update, 3: 123-126.

Sharma, M.P. and Singh, P.R. 1992. Development of tractor front mounted double row sugarcane windrower harvester. Indian J. Agri. Eng., 2(2): 102-105.

Singh, S., R.S. Singh and S.P. Singh. 2010. Farm Power Availability and Agriculture Production Scenario in India. Agri. Eng. Today, 34(1): 9-20.

USDA. 2013. Crop Production Summary USDA, National Agricultural Statistics Service.

Veerangouda, M., Sushilendra, K.V. Prakash and M. Anantachar. 2010. Performance 
Evaluation of Tractor Operated Yeljep and Mohammed. 2005. Effect of knife Combine Harvester. J. Agric. Sci., velocity on cutting energy and 23(2): 282-285.

Yadav, R.N.S. and M.P. Sharma. 2002. Performance Evaluation of Sugarcane Chopper Harvester. Sugar Tech., 4: 117-122. efficiency during impact cutting of sorghum. Agricultural Engineering International: The CIGR E-J., Manuscript PM 05004 Vol. VII.

\section{How to cite this article:}

Nikam, M.D., S.H. Thakare, V.P. Khambalkar and Karhale, S.S. 2017. Study of Economics of Manual and Mechanical Harvesting Method of Sorghum Crop. Int.J.Curr.Microbiol.App.Sci. 6(6): 1211-1217. doi: https://doi.org/10.20546/ijcmas.2017.606.140 